\title{
USE OF CELL PHONES BY THE FARMERS AS AN EXTENSION TOOL TO PRACTICE SUSTAINABLE AGRICULTURE AND ACHIEVE FOOD SECURITY IN THE KINGDOM OF SAUDI ARABIA
}

\author{
F. O. Aldosari, Mohamad S. Al-Sakran, Hammad F.N. Alkhubizi, Abdullah A. Al-Zaidi, Mirza B. \\ Baig, Muhammad Muddassir, Mehmood Ali Noor, Muhammad Mubushar
}

Department of Agricultural Extension and Rural Society, College of Food and Agriculture Sciences

King Saud University, P.O. Box 2460, Riyadh 11451

Kingdom of Saudi Arabia

Received - Feb 26, 2017; Revision - April 12, 2017; Accepted - April 15, 2017

Available Online - August 31, 2017

DOI: http://dx.doi.org/10.18006/2017.5(Spl-1-SAFSAW).S91.S98

KEYWORDS
Extension Education
Information dissemination
Sustainable Agriculture
Al-Delam farmers
Cell phone

* Corresponding author

E-mail: fadosri@ksu.edu.sa (F. O. Aldosari)

Peer review under responsibility of Journal of Experimental Biology and Agricultural Sciences.

Production and Hosting by Horizon Publisher India [HPI] (http://www.horizonpublisherindia.in/).

All rights reserved.

\begin{abstract}
This study sought to identify how farmers used mobile technology as an extension tool in the area of AlDelam, Saudi Arabia. The study population consisting of 277 farmers was drawn using face to face interview. Well-structured, pre-tested questionnaires were used to collect data. Results of the study are based on questionnaires completed in all respects by 196 participants (70.1\% of total). Data were analyzed using SPSS. Results of study revealed that approximately $77 \%$ of respondents were using mobile as an extension tool continuously (in routine) and about $68 \%$ of the respondents were of the opinion that cell phone helped them meeting their needs and achieving their goals related to agriculture. However, approximately $77 \%$ of farmers did not subscribe to any extension services and about $67 \%$ intended to subscribe in the near future. Regarding the use of the cell phones for agricultural purposes, about $60 \%$ farmers were using them to determine the price of agricultural inputs (e.g. seeds, fertilizers, and pesticides). The study also revealed that about $50 \%$ farmers used their cell phones to obtain information through calls, SMS and WhatsApp with the means of 2.86, 2.40 and 2.31, respectively on a 1 to 5 scale. The study concluded that the different categories of the farmers were meeting their needs for agricultural information from different information sources. However, the study showed a positive and significant correlation between larger farmers and the use of cell phone as an extension tool to seek agricultural information at the significance level of 0.01 .
\end{abstract}

All the article published by Journal of Experimental Biology and Agricultural Sciences is licensed under a Creative Commons Attribution-NonCommercial 4.0 International License Based on a work at www.jebas.org.

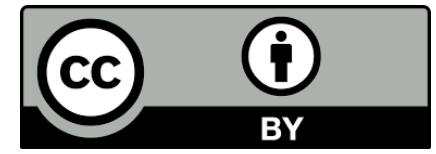




\section{Introduction}

In a new paradigm, cell phone users have increased exponentially. There were 6.8 billion cell phone subscribers in 2012 globally, according to International Telecommunication Union (2003) estimation. During the last decade, Information Communication Technologies (ICT) did receive significant attention and had a multi-dimensional positive impact on agriculture and rural poverty reduction in the remote areas (Bhavnani et al., 2008; Leye, 2009). ICT has proved to overcome traditional extension systems barriers by enhancing inter-personal connections and increasing their access to information about local markets for price and input availability, ebanking and lowering transaction costs (Bayes, 2001; Gupta, 2005; Malhan \& Rao, 2007; Tchouassi, 2012; Arayesh, 2015). Further, Kashem (2009) recognized that the cell phone, attaining the $5^{\text {th }}$ position among all the 12 communication media employed by the rural farmers to seek agricultural information while ignoring the previously used traditional communication, electronic and interpersonal media.

Burke \& Sewake (2008) maintain that the mobile internet provides significant volume of useful information related to agriculture and its associated problems. Online knowledge and information regarding banking has emerged as a successful initiative in promoting agri-business among farming communities. According to Shaibu \& Powell (2008), cell phones can be used to provide information on agricultural markets to the farmers that inturn can enhance their bargaining power while marketing their agricultural commodities. The study, conducted in Ghana, revealed that farmers directly connected with the buyers through cell phones receive better prices for their agricultural goods as compared to using the brokers. Farmers with the cell phones can eliminate transport cost (Overa, 2006) while saving money, time and energy by avoiding going to the markets (Muto \& Yamano 2009; Muto \& Yamano., 2011; Lee \& Bellemare, 2013). Cell phone-enabled technologies are also used to monitor and disseminate information about the out breaking of crop diseases (Ndyetabula \& Legg, 2011; Kefala, 2011). Similarly, Murthy (2009) also maintains that SMS services used through cell phones can keep farmers updated on weather conditions and insects/pests in their fields.

A study conducted by the World Bank on the consumer behavior in the Philippines showed that the users of cell phone were realizing higher growth rates (11-17\%) in their earned incomes (Labonne \& Chase, 2009). Another study indicated the farmers having cell phones in Morocco were able to increase their average incomes by nearly $21 \%$ (Ilahiane, 2007). Adamides \& Stylianou (2013) revealed that nearly $98 \%$ of the farmers in Cyprus were using cell phone as the medium to seek information on innovations in agriculture.

Despite these tremendous advancements, the grain yields are still questionable among the small landholders in many developing countries due to lack of timely information, non-availability of inputs and skill gaps including improved farming technologies and management practices (Qiang et al., 2009). However, many such issues and constraints can be removed by proving the farmers with the appropriate technologies in the timely fashion by employing suitable extension tools and approaches like ICT - cell phones.

Though the traditional extension approaches and tools have been evaluated for their usefulness and impact on the farmers and farming in the Kingdom of Saudi Arabia yet the use of modern ICT technologies, particularly cell phones, have not been tried as an agricultural extension tool so far. Present study is an endeavor to explore how the farmers use their cell phones as a tool to have extension advices and gather information on the variables that facilitate or obstruct its use.

\subsection{Research problem}

In the technically advanced countries, the Agricultural Extension Services and famers are using ICT - cell phones for providing information on various aspects of agriculture. However, the potential role, impact and extent of use of cell phones have not been studied in the Kingdom. The information gap prompted the researchers to identify how the farmers using cell phones seek agricultural information and explore the variables that facilitate or obstruct its mass scale application in the field.

\subsection{Objectives of the study:}

This study was conducted to identify the farmers using the cell phone technology as an extension tool for obtaining agricultural information. Second objective of the study was to explore the relationship between farmers' socio-economic characteristics and the use of cell phone technology as an extension tool. Further, study was also conducted to identify the variables obstructing or facilitating the use of cell phone technology as an extension instrument.

\section{Materials and Methods}

\subsection{The methodology and the study area}

Al-Delam, is an area located in center of Saudi Arabia which is 20 $\mathrm{km}$ away from the Governorate of Al-Kherj and $100 \mathrm{~km}$ from the capital Al-Riyadh, Saudi Arabia. It lies between longitude $47^{\circ}$ $48^{\circ} \mathrm{E}$ and latitude $23.5^{\circ}-24.5^{\circ} \mathrm{N}$ and 1360 feet high from sea level. Al-Delam has a population of 70,000 people with the total land area of $250,000 \mathrm{~m}^{2}$. In the east side of the Al-Delam, a series of sand dunes known as Dhahbi and in the west side hills are present which is famous due to 'Jabal Abu Wald' and at north side 'Na'jan' surrounded by Wadi Turki having two branches known as; Wadi Al-Hssani and Wadi Al-Jarif that topography are also sandy. 


\subsection{Sampling procedure}

A comprehensive study was conducted in Al-Ain, Al-Raweeb, AlSahna, Al-Adhar, Al- Mohammadi, Mawan, Al-Aqeemi, Na'jan and Rameeqa situated in Al-Delam. The total registered farmers in Al-Delam were 986 (Ministry of Agriculture, 2013). A simple random technique was used to select (277) respondents, about $28 \%$ of the total population. All respondents (277) were interviewed (face to face). About 81 respondents that account for $19.9 \%$ of the study population did refuse to respond and rest of the $196(71.0 \%)$ respondents participated, furnishing the required information out of the 277 farmers.

\subsection{Data collection and analysis}

Data were collected against the properly designed questionnaire written in the very simple and straight Arabic language avoiding technical and scientific terms. Both descriptive as well as inferential statistical tools were employed to analyze. Descriptive statistics such as frequency counts, percentage and means were used to analyze and make the findings of the study more meaningful. Pearson-product correlation was used to identify the relationship between the farmer's socioeconomic characteristics and the cell phone technology used for seeking advice and services related to agriculture.

\section{Results and Discussion:}

In this section we discussed the results obtain from the field study that includes; socio-economic attributes of the respondents, information source regarding use of cell phone as an extension tools and the nature of relationship between farmers socioeconomic characteristics and use of cell phone technology as an extension tools.

\subsection{Socio-economic attributes of the respondents}

Socio-economic characteristics of the respondents in table 1 showed that the farmers associated with agricultural activities with an age of 42 years or below account for $30.6 \%$ while the age group between $42-52$ years accounts for $53.6 \%$ of total population. Approximately $16 \%$ of the respondents are above 52 years old. Mean age of the respondents was 47.6 with the standard deviation of 10.7. This means that a vast majority of respondents belonged to middle age group and the youth were not participating in the agricultural activities in Al-Delam area.

Education is known as an investment in the human capital that increases labor productivity, reduces income inequality and certainly poverty (Amin \& Awung, 2005). Alene \& Manyong (2007) suggested that education had the positive effect on the adoption of new technologies and the innovations. Results of the present study revealed that some $39.8 \%$ of the respondents associated with agriculture had a college level education followed by the $32.1 \%$ respondents with secondary level education whereas only $5.1 \%$ respondents out of total population had received their university education. It can be speculated that university graduates get better and well-paid jobs, earning more than they could make in agriculture. The study also revealed that majority of respondents participated in agriculture not as their first profession but opted as an additional source of income. Approximately $40 \%$ of the respondents considered agriculture as their primary source of income while $8.3 \%$ respondents were in the farming business to supplement their basic source of income. Only $1 \%$ stated they were farming for entertainment. The majority of the respondents (62.2\%) owned farmlands and some $25 \%$ farmers were renting farms. Only $7.7 \%$ farmers were practicing agriculture in partnership. The majority of the respondents $(53.1 \%)$ had farming experience ranging between 17 to 33 years. Approximately $31 \%$ of the respondents were with an experience of greater than 17 years. Only $15.8 \%$ of the respondents were in the farming business with greater than 33 years of experience. The average farming experience of respondents was 18.1 years with the standard deviation of 11.1.

Data in table-1 revealed that majority of the respondents $(51.1 \%)$ had small land-holdings followed by $40.8 \%$ with the medium land holdings and $7.7 \%$ respondents (Mean 28.9 and SE 41.1) were with the landholdings more than 50 hectares. Concerning annual income, about $25.5 \%$ respondents earned SAR 200,000 - 300,000 per year from agriculture.

\subsection{Distribution of respondent's attitude regarding cell phone use and source of information}

The majority of the farmers (77\%) in the present study were the permanent and regular users of the cell phones. Only $18.9 \%$ respondents have been found to be partial users, while $4.1 \%$ were not using mobile at all. Maximum numbers of farmers prefer to get agricultural information from the farmers in their neighborhood. Some $83.2 \%$ farmers were permanently depending on neighboring larger scale farmers whereas only $14.8 \%$ were dependent partially on the neighboring farmers. Approximately $71 \%$ of the farmers were permanently dependent on their friends and relatives and about $13.8 \%$ respondents were partially relying on their friends and relatives. Some $67.9 \%$ farmers were obtaining information from corporate marketing agents while only $21.4 \%$ partially used their services. Alnethmah Agriculture Fund and Agriculture Information Centers were used the least when obtaining information on agriculture. Only $2.6 \%$ of the farmers utilized the services of both the sources. Farmers showed lack of interest in the other public institutions as well and relied more on the progressive farmers, close friends, and private companies for satisfying their needs for information related to agriculture (Table 2). 
Table 1 Socio-economic characteristics of study area farmers

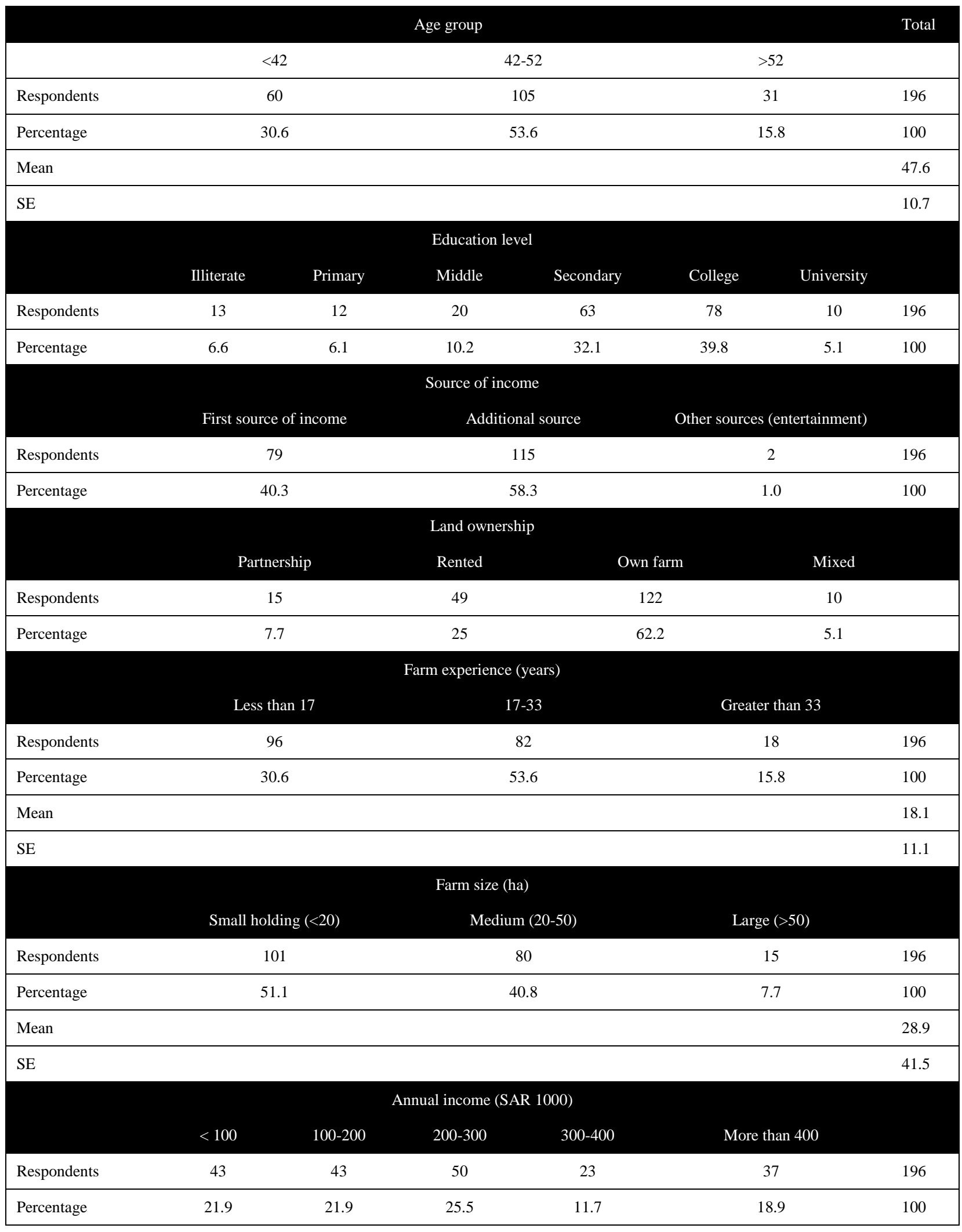


Table 2 Distribution of respondent's attitude regarding cell phone use and source of information

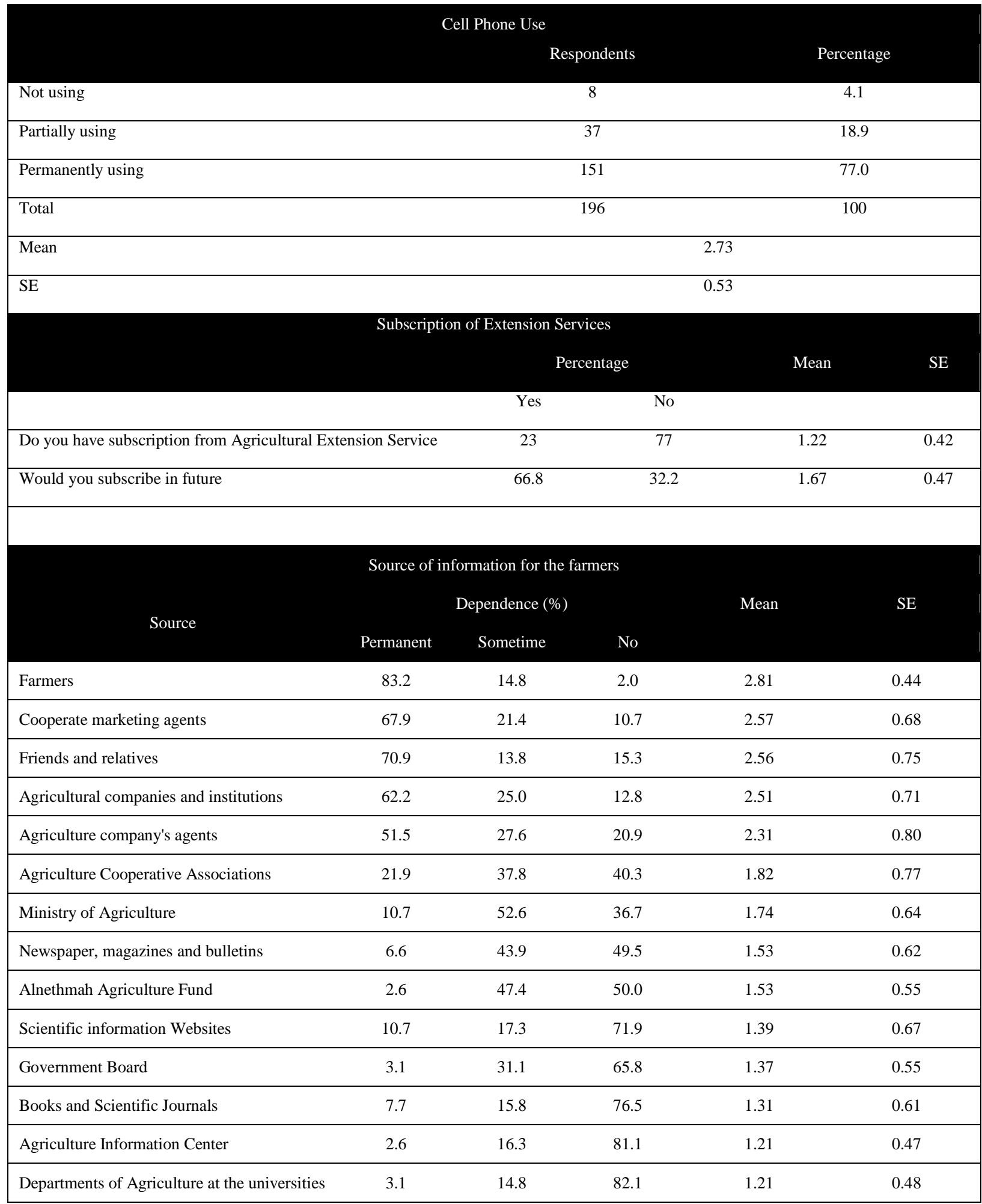




\subsection{Correlation between farmer's socioeconomic} characteristics and use of cell phone technology as an extension tools

The study shows a positive correlation $(0.153 *)$ between cell phone ownership and its usage as an extension tool for getting agricultural information through different modes like Calls, SMS, Whatsapp (Table 3). Researchers like Qiang et al., 2011; Aker, 2011, and Donner, 2009 showed that farmers who owned cell phones readily get information about inputs, crops health and marketing, and the availability of timely information certainly help improving livelihoods of the farmers. Although, it is an assumption that every single farmer knows the commodity price, due to high illiteracy and the involvement of the middlemen, it is not common in the developing countries.

Table 3 Correlation between uses of cell phone as an extension tool and farmer characteristics

\begin{tabular}{|lc|}
\hline \multicolumn{1}{|c|}{ Independent variable } & Spearman correlation \\
\hline Age & -0.136 \\
\hline Education level & 0.126 \\
\hline Occupation & -0.137 \\
\hline Type of land ownership & 0.043 \\
\hline Full time farm work & -0.065 \\
\hline Experience in agriculture & 0.038 \\
\hline Total area of the farm & $0.193 * *$ \\
\hline Farm supervision & 0.045 \\
\hline Types of labor & $-0.150^{*}$ \\
\hline Annual income & 0.069 \\
\hline Information source & 0.116 \\
\hline *p=.05 **p=.01
\end{tabular}

Farmers know little about the market price in the urban areas of their own country. However, in such situations cell phones can help provide up-to-date information to both the producers and consumers and reduce the price gap. Results of the present study are in line with (Jensen, 2007) as he stated that cell phone use equalizes prices of the small gains in the whole of a particular region and ensures welfare of the consumers as well.

The study revealed a positive correlation $(0.193 * *)$ between land ownership of the small-scale farmers and the use of the cell phones. Since the progressive farmers with large land areas use inputs wisely and also adopt innovative management practices to increase their farm incomes, it has been observed that the small farmers follow the advice of the progressive farmers to enhance their farm incomes as well. Small farmers might use cell phones to make calls, send SMS or WhatsApp before visiting the progressive farmers in order to access agricultural information. The study revealed that the progressive farmers were carrying more credible agricultural information with higher financial resources to buy inputs whereas the small farmers were only using the cell phone to get agricultural information through Calls, SMS or WhatsApp.

The use of cell phone helps the farmers by proving them with the information on various features associated with agriculture like: weather forecast, and pests and diseases outbreaks. In addition, they use their cell phones to learn more about agricultural inputs such as seed, fertilizers, and pesticides (Preethi, 2009). This device has given new direction and approach to the farmers to communicate directly and share the recent advances with each other. The studies revealed that farmers were able to save energy and time due to the use of cell phones that ultimately increase their net incomes. Cell phones have enabled the farmers to communicate directly with the market brokers and customers for the sale of their produce on the acceptable prices (Chhachhar et al., 2014). The study revealed a negative correlation $(-0.150 *)$ between the use of cell phone and the type of labor as most of the laborers, hired on wages, did not have cell phones.

\section{Conclusions and recommendations}

The use of cell phone technology can act as an important change agent in many developing countries. This technology keeps the farmers up-dated on essential information like weather forecast, agricultural practices, and marketing and prices of the commodities. This study showed that larger farmers realize more benefits due to ICT - cell phones by improving their farm productivity and for having better market information about the sale of farm commodities. The study revealed that the small farmers were using cell phones to gather information on production technologies and crop management practices from the larger farmers. Small farmers used cell phones to make calls, send SMS and WhatsApp. They were also frequently using cell phones to facilitate their visits to the larger farms and to consult with the larger farmers to seek their advice and collect information on the new farming practices and technologies.

\section{Acknowledgement}

The authors are extremely thankful to the King Saud University, Deanship of Scientific Research for extending all the possible assistance and support towards the completion of the research project.

\section{References}

Adamides G, Stylianou A (2013) ICT and Cell phone Use for Agricultural Knowledge Sharing by Cypriot Farmers. Agris online Papers in Economics and Informatics 3-10. 
Aker JC (2011) Dial "A" for Agriculture: Using Information and Communication Technologies for Agricultural Extension in Developing Countries, Working Paper No. 269. Center for Global Development, Washington D.C.

Alene AD, Manyong VM (2007). The effects of education on agricultural productivity under traditional and improved technology in northern Nigeria: an endogenous switching regression analysis. Empirical Economics 32: 141-159.

Amin AA, Awung WJ (2005) Economic Analysis of Private Returns to Investment in Education in Cameroon. Regional Conference on Education in West Africa: Constraints and Opportunities. Dakar Senegal: African Institute for Economic Development and Planning (IDEP).

Arayesha MB (2015) Investigating the Relationship between Technical and Legal Factors with Tendency of Villagers to Use EBanking Services (Case Study: Agricultural Bank Branches in Ilam). $6^{\text {th }}$ World conference on Psychology Counseling and Guidance, 14 - 16 May.

Bayes A (2001) Infrastructural and rural development: insights from a Grameen Bank village phone initiative in Bangladesh. Agricultural Economics 25: 261-272.

Bhavnani A, Chiu RWW, Janakiram S, Silarszky P, Bhatia D (2008). The role of mobile phones in sustainable rural poverty reduction. Retrieved November 22, 2008.

Burke K, Sewake K (2008) Adoption of computers and internet technology in small firm agriculture: A study of flower growers in Hawaii. Journal of Extension 46: 519.

Chhachhar AR, Qureshi B, Khushk GM, Ahmed S (2014) Impact of Information and Communication Technologies in Agriculture Development. Journal of Basic and Applied Scientific Research 4: 281-288.

Donner J (2009) Mobile-based Livelihood Services in Africa: Pilots and Early Deployments. In: Fernandez-Ardevol M, Híjar AR (Eds.), Communication Technologies in Latin America and Africa: A Multidisciplinary Perspective. IN3, Barcelona, Pp. 3758.

Gupta DK (2005) Modern encyclopedia of media and mass communication. Vol.1, Rajat Publications, New Delhi, India.

Guenthner JF, Swan BG (2011) Extension learners' use of electronic technology. Journal of Extension 49: 1-9.

Ilahiane H (2007) Impacts of Information and Communication Technologies in Agriculture: Farmers and Cell phones in Morocco." Paper presented at the annual meetings of the American Anthropological Association, December 1, Washington,
DC. IT News Online. 2010 . http://www.itnewsonline.com/news/Nokia,-Tata-DOCOMO-toOffer -Ovi-Life-Tools-in-Rural, Semi-Urban-India/19934/7/1, accessed May 2011.

Jensen R (2007) The Digital Provide: Information (Technology), Market Performance, and Welfare in the South Indian Fisheries Sector. Quarterly Journal of Economics 122 :879-924.

Kashem MA, Etages HD, Kopitar- Jerala N, McGregor IS, Matsumoto I (2009) Differential protein expression in the corpus callosum (body) of human alcoholic brain. Journal of Neurochemistry $110:$ 486-495.

Kefala GT (2011) The impact of cell phone and economic growth in developing countries. African Journal of Business Management $5: 269-275$.

Labonne J, Chase RS (2009) The Power of Information: The Impact of Cell phones on Farmers' Welfare in the Philippines. Policy Research Working Paper No. 4996. Washington, DC: World Bank.

Lee KH, Bellemare MF (2013) Look who's talking: the impacts of the intra house hold allocation of cell phones on agricultural prices. The Journal of Development Studies $49: 624-640$.

Leye V (2009) Information and Communication Technologies for Development: A Critical Perspective. Global Governance 15: 2935.

Malhan IV, Rao S (2007) Impact of globalization and emerging information communication technologies on agricultural knowledge transfer to small farmers in India. World Library \& Inform. Congress, $73^{\text {rd }}$ Ifla General Conf. \& Council, 19-23 Aug. 2007, Durban, South Africa.

Ministry of Agriculture (2013) Statistics Department, Kingdom of Saudi Arabia. Unpublished data.

Murthy CSHN (2009) Use of convergent mobile technologies for sustainable economic transformation in the lives of small farmers in rural India. Turkish Online Journal of Distance Education 10: $32-4$.

Muto M, Yamano T (2011) Cell phone Coverage and Market Participation: The Case of Banana Marketing in Uganda Emerging Development of Agriculture in East Africa. Springer publication, Netherland 99-113.

Muto M, Yamano T (2009) The Impact of Cell phone Coverage Expansion on Market Participation: Panel Data Evidence from Uganda. World Development 37 :1887-1896.

Ndyetabula I, Legg J (2011) DEWN Digital Early Warning Network. R4D Review, 6 . 
Overa R (2006) Networks, Distance, and Trust: Telecommunications Development and Changing Trading Practices in Ghana. World Development 34:1301-15.

Preethi J (2009) Reuters Market Light Goes Pan-India with Nokia. MediaNama, http://www.medianama.com/2009/04/223- reutersmarket-light-goes-to-himachal-pan-india-with-nokia-txt-vs-gprsvs-voice/, accessed October 2010.

Qiang CZW, Kuek SC, Dymond A, Esselaar S (2011) Mobile Applications for Agriculture and Rural Development. World Bank, Washington D.C.

Qiang, Zhen-Wei C, Rossotto C, Kimura K (2009) Economic Impacts of Broadband. In: Information and Communications for
Development. Washington D.C.: World Bank.

Subba Rao S (2004) "Role of ICTs in India's rural community information systems", info, Vol. 6 Issue: 4, pp.261-269, https://doi.org/10.1108/14636690410555663

Tchouassi G (2012) Can Cell phones Really Work to Extend Banking Services to the Unbanked? Empirical Lessons from Selected Sub-Saharan Africa Countries. International Journal of Developing Societies 2: 70-81.

The International Communications Union (ITU) The World in 2013: ICT facts and figures. 2013. Available:http://www.itu.int/en/ITUD/Statistics/Documents/facts/ ICTFactsFigures2013. Pdf. 